\title{
Code Book
}

\begin{tabular}{|c|c|c|}
\hline & Code & Description of Code \\
\hline \multicolumn{3}{|c|}{ RQ1: What tensions emerged over technology use between parents and teens? (RQ 1) } \\
\hline 1 & $\begin{array}{l}\text { Adapted Practices that Led to Technology-Related } \\
\text { Tensions }\end{array}$ & $\begin{array}{l}\text { Aspects of the old practices that families had to change and that } \\
\text { led to technology-related tensions. These changes were parent- } \\
\text { driven. E.g., schedule-driven use of Internet instead of using it } \\
\text { out of one's convivence. }\end{array}$ \\
\hline 1.1 & AdaptingPractice_ParentalReason & $\begin{array}{l}\text { Reasons that led parents to change their old practices. For } \\
\text { example, everybody gets Internet access when they are } \\
\text { completing essential daily tasks or mothers can get 'close-to- } \\
\text { ideal' work spaces }\end{array}$ \\
\hline 1.2 & AdaptingPractice_TeensPerception & $\begin{array}{l}\text { Teens perception about the changes to old practices. For } \\
\text { example, teens understood parents' decision to coordinate } \\
\text { Internet access. }\end{array}$ \\
\hline 1.3 & AdaptingPractice_Challenges & $\begin{array}{l}\text { Includes difficulties families faced while implementing changes } \\
\text { in old practices. For example, when the new parent in charge of } \\
\text { mediating teens' technology had limited technological skills it } \\
\text { was easy for teens to obscure their actual use of devices. }\end{array}$ \\
\hline 1.4 & AdaptingPractice_TechnologyUseRestrictions & $\begin{array}{l}\text { Adaptations to old practices impacted teens' technology use } \\
\text { through changes in parental technology-related restrictions. For } \\
\text { example, new and/or increased activity- or context-specific } \\
\text { restrictions were applied }\end{array}$ \\
\hline 1.5 & $\begin{array}{l}\text { AdaptingPractice_Perceptions Related to Teens' } \\
\text { Technology Use and Restrictions } \\
\text { - } \quad \text { Teens_perception_self } \\
\text { - } \quad \text { Teens_peceptions_parent } \\
\text { - } \quad \text { Parents_peceptions_self } \\
\text { - } \quad \text { Parents_peceptions_teen }\end{array}$ & $\begin{array}{l}\text { Parents' and teens' perceptions about the actions of self and other } \\
\text { in regard technology use and restrictions. } \\
\text { - } \\
\text { Teens_perception_self: independence to use } \\
\text { technology is important given the circumstances, } \\
\text { involvement in decision-making is important, trying } \\
\text { best to abide by restrictions despite the difficulty and } \\
\text { confusion. } \\
\text { - Teens_perception_parent: supportive attempts are } \\
\text { insufficient for parents. } \\
\text { - Parents_perception_self: changes are inescapable and } \\
\text { challenging } \\
\text { Parents_perception_teen: teens undermine policies } \\
\text { intentionally, teens will shift focus from school-work } \\
\text { without limits }\end{array}$ \\
\hline 2. & $\begin{array}{c}\text { Other Changes in Technology Restriction } \\
-\quad \text { Decrease in Limits } \\
-\quad \text { Increase in Limits }\end{array}$ & $\begin{array}{l}\text { Changes in technology restrictions that were not due to adaption } \\
\text { to old practices or were not corresponding to new resilient } \\
\text { practices. Parents } \\
\text { - Decreased some activity- or context-specific limits: for } \\
\text { example, daily screen time limit was decreased } \\
\text { (context-specific) } \\
\text { - Parents increased activity- or context-specific some } \\
\text { limits: for example, no use during weekends. }\end{array}$ \\
\hline 3 & $\begin{array}{c}\text { Process of Imposing Changed Technology Restrictions } \\
\text { - Comparing during-COVID process and Pre- } \\
\text { COVID technology restrictions process }\end{array}$ & $\begin{array}{l}\text { Mediation strategies followed for imposing new or increased } \\
\text { restrictions on technology use of teens during COVID-19, e.g., } \\
\text { restrictive mediation. These exclude the process followed for } \\
\text { restrictions corresponding to technology use for resilience- } \\
\text { building practices. } \\
\text { Sub code includes: } \\
\text { - Comparing during COVID-times process with that of } \\
\text { pre-COVID times: for example, parents followed } \\
\text { restrictive mediation instead of their pre-COVID } \\
\text { process of combining of restrictive and active } \\
\text { mediation and co-viewing }\end{array}$ \\
\hline
\end{tabular}




\begin{tabular}{|c|c|c|}
\hline 4. & $\begin{array}{l}\text { Overall Perceptions about Teens' Technology Use and } \\
\text { Restrictions } \\
\quad \text { - Teens' feelings_about_parents } \\
\text { - } \quad \text { Parents_perceptions_restrictions }\end{array}$ & $\begin{array}{l}\text { Feelings about the overall change in teen's technology use and } \\
\text { restrictions (excluding the changes that came because of } \\
\text { technology-enabled resilient practices). } \\
\text { Sub-codes include: } \\
\text { - Teens feeling about how parents perceive teens' use } \\
\text { and impose the restrictions: parents have double } \\
\text { standards due to no reciprocation of trust, parents do } \\
\text { not follow the same rules, or because teens were not } \\
\text { involved } \\
\text { - Parents' own feelings about imposing the restrictions: } \\
\text { guilt, felt position was justified }\end{array}$ \\
\hline
\end{tabular}

Code

Description of Code

RQ2: How did parents and teens use technology to build resilience as they adapted to new daily routines? (RQ 2)

\begin{tabular}{|c|c|c|}
\hline 2 & $\begin{array}{l}\text { Technology-Driven Resilient } \\
\text { Practices }\end{array}$ & $\begin{array}{l}\text { New Practices that became part of families "new normal" [47] due to the critical role of } \\
\text { technology and contributed to family resilience }\end{array}$ \\
\hline 2.1 & $\begin{array}{l}\text { Role of Technology in Conducting } \\
\text { the Practice } \\
\quad-\quad \text { Technology Used }\end{array}$ & $\begin{array}{l}\text { Critical ways in which technology enabled people to adopt the resilient practices. For } \\
\text { example, shared online documents afforded parents to asynchronously engage in } \\
\text { meaning making as synchronous engagements at a preferred depth and frequency were } \\
\text { difficult due to conflicting schedules } \\
\text { Sub-code includes: } \\
\text { Technology Used: Specific applications and/or devices used. }\end{array}$ \\
\hline 2.2 & Reasons to Adopt Practices & $\begin{array}{l}\text { Aspects of disruption that led parents to adopt the practices. For example, uncertainty } \\
\text { caused by the disruption or restrictions on face-to-face socializing. }\end{array}$ \\
\hline 2.3 & Prior experience with the Practice & $\begin{array}{l}\text { Aspects of resilient practices that were part of the daily lives before COVID-19. E.g., } \\
\text { using Facebook for connecting with Friends. }\end{array}$ \\
\hline 2.4 & $\begin{array}{l}\text { Goals that were Accomplished due to } \\
\text { Resilient Practices } \\
\begin{array}{cl}\text { - } & \text { Individual-Level goals } \\
- & \text { Family-Level goals }\end{array}\end{array}$ & $\begin{array}{l}\text { Resilient practices led parents to achieve individual-level or family-level goals or both. } \\
1 \text { Family-level goals included, for example, developing a shared understanding of the } \\
\text { crisis, gaining access to resources. } \\
\text { 2. Individual-level goals included, for example, getting glimpse into adults' world } \\
\text { (teens), receive support in caregiving (parents). }\end{array}$ \\
\hline 2.5 & $\begin{array}{l}\text { Technology Use } \\
\text { Restrictions_resilience-building } \\
\text { practices } \\
\quad-\quad \text { Reasons_NoTensions }\end{array}$ & $\begin{array}{l}\text { Mediation of technology use for resilient practices, for example, technology use } \\
\text { resilient practices was not account the use in daily screen limits, but was time-bound. } \\
\text { Sub codes includes: } \\
\text { - Reasons_NoTensions: Factors that ensured no tensions emerged between } \\
\text { parents and teens, despite the restrictions imposed on technology use for } \\
\text { resilient practices }\end{array}$ \\
\hline
\end{tabular}

Please note all these codes listed aspects from both low-SES and high-SES families, which allowed us to compare the differences and similarities in the two group of participants. 